\title{
A IGREJA CATÓLICA E A ESCRAVIDÃO NEGRA NO BRASIL A PARTIR DO SÉCULO XVI
}

PEREIRA, Tulio Augusto de Paiva ${ }^{1}$

PEREIRA, Tulio Augusto de Paiva. A Igreja Católica e a Escravidão Negra no Brasil A Partir Do Século XVI. Revista Científica Multidisciplinar Núcleo do Conhecimento. Ano 03, Ed. 05, Vol. 05, pp. 14-31, Maio de 2018. ISSN:2448-0959

\section{RESUMO}

A participação da Igreja Católica no processo de implantação e manutenção da escravidão negra africana no Brasil, a partir do século XVI, se deu de diversas formas e, isto foi possibilitado pela instituição de uma união entre o Estado português e a Igreja, chamado de "padroado real". Esta união, na verdade, subordinava a Igreja ao Estado português em troca da exclusividade da ação evangelizadora nas terras descobertas, visando aumentar o seu número de seguidores. Por outro lado, a Igreja e a religiosidade foram utilizadas na justificação do sistema colonial, de cunho mercantilista, voltado para a geração de riquezas para Portugal. A escravidão negra se tornou um dos pilares na estruturação da sociedade e da economia colonial. Porém, este era um sistema hediondo de exploração humana para estar ligado a uma instituição que foi criada para promover a fraternidade, a justiça e a paz entre os homens. Este trabalho discute estas questões.

\footnotetext{
${ }^{1}$ Graduação em Administração pela Pontifícia Universidade Católica de Minas Gerais - 1990; Graduação em Ciências Contábeis pela Faculdade de Ciências Econômicas, Contábeis e Administração de Varginha MG - 1993; Especialização em Administração Pública pela Faculdade de Ciências Econômicas, Contábeis e Administração de Varginha MG - 2002; Graduação em História pelo Centro Universitário Dr. Edmundo Ulson de Araras SP - 2014; Especialização em Ensino de História e Geografia pelo Centro Universitário Claretiano de Batatais SP - 2015.
} 
Palavras-chave: Padroado Real, Justificação, Exploração, Fraternidade.

\section{INTRODUÇÃO}

Este trabalho foi desenvolvido na modalidade de um artigo científico, baseado na revisão bibliográfica de obras que abordam o tema da influência e da participação da Igreja Católica na implantação da escravidão negra no Brasil a partir do século XVI, sendo consultadas e confrontadas diversas fontes, com o objetivo de se chegar a conclusões imparciais sobre $\mathrm{o}$ assunto que está sujeito a diversas interpretações.

O objetivo do trabalho é analisar a influência e a participação da Igreja Católica no processo, não somente, de implantação da escravidão negra no Brasil a partir do século $\mathrm{XVI}$, mas também, os motivos que levaram à manutenção e ao fortalecimento deste sistema de mão-de-obra utilizado no país nos tempos de sua colonização até finais dos tempos do império, ou seja, estudar como a religião e, mais especificamente, a Igreja Católica acabou sendo utilizada para justificar tal situação. Não se trata de julgar as ações e as atitudes da Igreja naquela época, mas tão somente de descrever os fatos a partir do ponto de vista dos diversos autores pesquisados que estudaram e escreveram sobre o tema.

Analisando a história da Igreja no Brasil fica notório o posicionamento de muitos autores, principalmente daqueles ligados à Igreja, que tratam do assunto de uma forma "triunfalista", ou seja, apenas ressaltando as grandes conquistas e realizações da Instituição e de seus principais personagens, enaltecendo e engrandecendo os grandes nomes de seus quadros; nomes estes, que acabaram se tornando também importantes figuras da história do país. Outros autores defendem que a história deve ser analisada a partir de um discurso situado no tempo e no espaço, ou seja, visualizam os erros e acertos das ações da Igreja e dos religiosos e destacam que os mesmos devem ser avaliados em relação à mentalidade da época, ao que era aceito como certo ou errado naquele momento histórico pela sociedade. Já outros autores, mesmo ligados à Igreja e, principalmente, aqueles independentes da mesma assumem uma posição mais crítica e expõem os problemas, as falhas e os "pecados" cometidos pela instituição ao longo de sua trajetória no Brasil, muitas vezes como 
forma de se entender melhor os motivos que a levaram a seguir tais caminhos e de se evitar que os erros sejam repetidos ou, em outros casos, como forma de se condenar a Igreja e a religião pelos mais diversos motivos.

Especificamente, em relação à escravidão negra no Brasil colonial, a primeira grande pergunta a ser respondida se refere ao não envolvimento da Igreja Católica na defesa dos negros africanos, numa posição antagônica ao seu envolvimento na defesa da não escravização do indígena que sempre foi muito dinâmica e fervorosa.

Um segundo ponto a ser analisado, neste trabalho, se refere à utilização da Igreja e de seus preceitos para justificação do sistema, tanto perante os portugueses brancos colonizadores, como perante os próprios negros para aceitação de sua condição desumana de exploração, facilitando, assim, a manutenção e o fortalecimento desta condição.

Diante da situação descrita acima, merece ser analisada e discutida a união ocorrida entre a Igreja Católica e a Coroa Portuguesa no projeto colonial brasileiro, chamada de "padroado real" e, ainda, até que ponto esta união influenciou o posicionamento da Igreja em prol da aceitação e até mesmo da justificação do sistema que não respeitava o ser humano, no caso, o negro africano escravizado.

$\mathrm{Na}$ dinâmica da evolução dos fatos, deve ser analisado como esta problemática evoluiu dentro da História do Brasil, fazendo com que a Igreja, não só aceitasse e reforçasse o sistema, como também se tornasse usuária do trabalho escravo africano em suas propriedades, utilizando-se diretamente de métodos desumanos para a exploração da força de trabalho do negro, afastando-se, assim, de sua verdadeira missão pregada pelo seu mestre e mentor Jesus Cristo.

Porém, merece destaque também, a ação de muitos religiosos que agiram de acordo com a sua consciência e avaliação pessoal, independentes das amarras e das orientações da instituição e do governo, a partir de sua análise da situação e atuando em prol dos negros escravos de origem africana. 
O fato é que a Igreja Católica teve papel relevante na formação da sociedade e da cultura brasileira desde os tempos coloniais e, este trabalho procura estudar de forma imparcial como se deu esta influência e participação.

\section{A INFLUÊNCIA E A PARTICIPAÇÃO DA IGREJA CATÓLICA NA IMPLANTAÇÃO DA ESCRAVIDÃO NEGRA NO BRASIL A PARTIR DO SÉCULO XVI}

\section{A DISCUSSÃO SOBRE OS MOTIVOS}

Uma questão relevante é levantada por diversos autores que tratam do tema da escravidão do negro no Brasil: por quais motivos a Igreja Católica se calou diante deste problema no país a partir do século XVI, sendo condizente e até usuária de um sistema hediondo de exploração de seres humanos?

Contra todos os ensinamentos de Jesus Cristo - criador e inspirador da Igreja - que pregou principalmente a paz, a fraternidade, a igualdade, a justiça e o respeito entre os homens; a Igreja, nesta fase de sua história, se coloca ao lado da exploração, da violência, da desigualdade e do terror sobre pessoas indefesas, caçadas e aprisionadas como animais do outro lado do oceano e trazidas à força para o trabalho escravo, para o cativeiro, para os castigos horrorosos e para a morte em todo o continente americano e, mais especificamente, no Brasil.

Na verdade, não foi a primeira vez e nem a última em sua história, que a Igreja Católica participou, influenciou e apoiou a injustiça entre os homens, mas o objetivo deste trabalho é discutir este caso brasileiro, não com a intenção de julgar, mas de descrever e entender melhor a questão.

Tentando responder a questão acima, Moraes (1998, p.213) afirma que "na realidade os motivos da escravidão do negro africano no Brasil colonial foram muitos, e o universo criado pelo sistema escravista foi social e culturalmente bastante complexo e diversificado, não permitindo nenhum tipo de reducionismo e explicação simplificadora". Já Lima (2001, p.41) levanta a seguinte questão: "como a Igreja, tão 
intransigente na defesa da liberdade dos nativos, foi tão condescendente com a escravidão negra, a ponto de permiti-la e até usá-la"? O próprio autor afirma que é difícil explicar, porém arrisca dizer que tal atitude "deve basear-se na mentalidade da época".

Ainda, segundo Lima (2001, p.41), em 1537 foram editadas duas bulas papais por Paulo III - Veritas ipsa e Sublimis Deus - que condenavam de forma explícita a escravidão humana em todas as suas formas, assim dizendo: "os mesmos índios e todas as demais gentes que vierem à notícia dos cristãos, ainda que estejam fora da fé de Cristo, não serão privados, nem devem sê-lo, da sua liberdade, nem do domínio de seus bens e não devem ser reduzidos à escravidão". Lima (2001, p.42) conclui afirmando que "quanto a escravidão vermelha, isto é, à escravidão dos indígenas, a posição da Igreja foi sempre coerente, consoante com as bulas papais acima mencionadas".

Nesta mesma linha de questionamento da ação da Igreja em relação ao tema e à época, acrescentando ao negro africano todas as demais classes menos favorecidas que viviam no Brasil, Hornaert et al. (2008, p.9) coloca as seguintes perguntas: "as igrejas cristãs se estabeleceram entre os pobres? Serviram ao pobre como quem serve ao Senhor, conforme a recomendação evangélica?" Hornaert et al. (2008, p.11), mesmo, responde afirmando que "nossa história é escrita por mãos brancas, do ponto de vista dos vencedores e dominantes" e acrescenta que essa visão conservadora da história brasileira sempre defendeu o status quo, sendo um obstáculo à uma atuação renovadora por parte da Igreja ao longo dos séculos seguintes da nossa história.

Outro ponto importante levantado por Hornaert et al. (2008, p.142), concordando com Lima como citado acima, é que alguns autores, principalmente de dentro da Igreja, quando contam a história em suas obras, citam a Antropologia em sua defesa, afirmando que "todo discurso humano é relativo a um determinado lugar, que não existe discurso senão situado", atribuem "os erros do passado à mentalidade da época. Daí, o teor triunfalista ou progressista de quase todas as publicações acerca da História da Igreja no Brasil". Matos (2011, p.15) assume este ponto de vista 
afirmando que "qualquer interpretação do passado é necessariamente parcial e incompleta" e continua afirmando que "a história da Igreja no Brasil não deve ser isolada de seu contexto sociopolítico e econômico cultural, porque é exatamente nessa realidade concreta que a Igreja se faz presente e atua".

Hornaert et al. (2008, p.258) também destaca a distinção entre a defesa da Igreja para com a não escravização dos indígenas e sua omissão no caso do negro africano não somente no Brasil, mas em toda a América Latina: "por que os missionários eram frequentemente defensores tão árduos dos indígenas enquanto não assumiram a defesa dos africanos com o mesmo zelo?"

Como colocado anteriormente, este questionamento é comum nas diversas obras consultadas para realização deste trabalho: Wright (2009, p.115) afirma que "Deus certamente queria que os índios fossem livres", mas "sua compaixão era de certa forma seletiva: qual a melhor maneira de remover o terrível fardo das costas dos nativos americanos do que aumentar o número de escravos africanos negros que chegavam à colônia".

Fausto (2009, p.26) lembra também o tratamento dispensado ao índio pela legislação da época, o contraste com negro africano era marcante, pois, os indígenas "contavam com leis protetoras contra a escravidão, ainda que fossem pouco aplicadas e contivessem muitas ressalvas. O negro escravizado não tinha direitos, mesmo porque era considerado juridicamente uma coisa". Vale lembrar que estas leis foram elaboradas pela metrópole, muitas vezes, sob pressão dos jesuítas que tinham grande influência na Corte, e, segundo o próprio Fausto (2009, p.30) tinha "uma política definida com relação a questões vitais da colonização, como a indígena".

\section{AS EXPLICAÇÕES E AS JUTIFICATIVAS}

Diante desta discussão sobre os motivos que levaram à utilização da mão-de-obra escrava africana no processo colonial brasileiro, Moraes (1998, p.211) lança a seguinte questão: "por que a escravidão indígena foi substituída pela dos negros africanos na atividade econômica mais importante da colônia?" O mesmo autor 
responde afirmando que a historiografia tinha uma "explicação raciológica" que pregava que o índio era "preguiçoso" inapto ao trabalho ao contrário do negro; outra explicação se baseava em critérios econômicos segundo os quais, "os interesses mercantis do tráfico negreiro (oferta) teriam impulsionado a escravidão do negro no Brasil (procura), pois o tráfico era uma atividade econômica altamente rentável e servia como item de acumulação primitiva de capital". Fausto (2009, p.22) nesta mesma linha afirma que "diferentes formas de trabalho servil predominaram na América espanhola, enquanto a escravidão foi predominante no Brasil" e questiona: "por que se apelou para uma relação de trabalho odiosa a nossos olhos, que parecia semimorta, exatamente na época chamada pomposamente de aurora dos tempos modernos?" e "por que se optou de preferência pelo negro e não pelo índio?" As respostas para estas interrogações são que "nem havia grande oferta de trabalhadores em condições de emigrar como semidependentes ou assalariados, nem o trabalho assalariado era conveniente para os fins da colonização" e "o comércio internacional de escravos, trazidos da costa africana era em si mesmo um negócio tentador, que acabou se transformando no grande negócio da Colônia”.

Moraes (1998, p.188) concorda com esta explicação quando argumenta que "a escassa população portuguesa dificultava qualquer possibilidade de estabelecer uma política emigratória de mão-de-obra assalariada para a colônia" e também cita a lógica econômica imposta, na época, pela metrópole de se alcançar altos lucros com a exploração dos produtos coloniais tropicais, assim, "o custo da mão-de-obra deveria ser baixo".

Ainda segundo Moraes (1998, p.188) entre 1550 a 1560, os trabalhadores escravos nos engenhos açucareiros eram predominantemente índios, capturados nas matas ou "diretamente nas missões catequizadoras dos jesuítas", mas a partir de 1550 já chegaram "os primeiros escravos negros trazidos pelo Estado". "Entre 1560 e 1570 o tráfico e a entrada de escravos cresceu de forma incessante, a maioria deles destinada à lavoura canavieira do Nordeste, sobretudo Bahia e Pernambuco." Continuando, Moraes (1998, p.212) afirma que "a partir desse momento, o tráfico de escravos emergiu como um instrumento necessário para atender a demanda 
crescente de mão-de-obra da economia açucareira brasileira", sendo no início realizado pelo Estado português e, posteriormente, assumido por comerciantes particulares que se fixaram ao longo do litoral africano, estabeleceram uma rede de conexões comerciais entre África e Brasil e tornaram o tráfico uma fonte de lucro e acumulação de capital. Por fim, Moraes (1998, p.210) conclui seu raciocínio afirmando que "desde o início do período colonial o trabalho escravo foi um dos eixos principais de organização de nossa sociedade".

Também tentando responder a questão, Bueno (1997, p.33) afirma que "a controvérsia esteve no âmago da ação jesuítica, já que, embora antagônicos, catequese e colonialismo andaram sempre juntos. Os jesuítas lutaram contra a escravidão dos indígenas", mas "para defender os índios estimularam o tráfico de africanos".

Segundo Fausto (2009, p.26), a escravidão era uma "instituição já existente na África, e assim apenas se transportavam cativos para o mundo cristão onde seriam civilizados e salvos pelo conhecimento da verdadeira religião". Realmente, em relação à escravidão anteriormente existente na África, Narloch (2011, p.96) afirma que "entre a diversidade das culturas africanas, a escravidão funcionava como um traço comum", existiam caravanas de comércio escravo "muitos séculos antes de os europeus atingirem a costa oeste do continente. No século VII, logo depois da colonização árabe no norte da África, africanos do sul do Saara passaram a atravessar o deserto para vender, aos árabes, algodão, ouro, marfim e, sobretudo, escravos". Mas, segundo Macedo (2013, p.102), "os povos africanos subsaarianos não reduziam ao cativeiro seus congêneres, mas sim seus adversários ou estrangeiros"... "nesse sentido, os maiores promotores da escravidão na África foram os governos" visando o fortalecimento de seus exércitos e de seus reinos, além da centralização de sua administração. Continuando nesta mesma linha de raciocínio, de acordo ainda com Macedo (2013, p.101), "a finalidade não era a exploração econômica em larga escala, e também a perda da liberdade pessoal não era completa, pois os cativos permaneciam integrados ao grupo social dos vencedores". 
Portanto, Macedo (2013, p.103) afirma que "a escravidão assumiu outro significado quando passou a ser integrada nas relações comerciais de longo curso", ou seja, o tráfico escravo para a colonização do continente americano, pois, neste caso, o ser humano - o negro africano - passava "por um duplo processo de desenraizamento", era retirado à força da sociedade a que pertencia na África, era levado para uma terra longínqua e, finalmente, era recolocado num ambiente estranho em uma posição de total submissão, subordinado a outra cultura, onde sofria a violência física, mental e sexual de seu corpo, era tratado como simples objeto, totalmente desprovido de um espaço digno para convivência com seus pares e com a comunidade em que era reinserido. "A existência de escravos africanos negros é comprovada já no tempo das cidades greco-romanas. Mas os contingentes eram baixos", algo totalmente diferente do tráfico internacional pelo Oceano Atlântico empreendido entre a metade do século XV e a metade do século XIX pelos europeus. Sobre a condição do negro neste comércio, Macedo (2013, p.105) afirma que o cativo, a partir de então, se tornou simplesmente um número, uma peça, uma mercadoria mesmo, "cujo valor podia oscilar de acordo com a lei da oferta e da procura". Na questão do valor do escravo, Fausto (2009, p.24) afirma que "durante a primeira metade do século XVII, nos anos de apogeu da economia do açúcar, o custo de aquisição de um escravo era amortizado entre treze e dezesseis meses de trabalho".

Segundo Narloch (2011, p.99), "eram os próprios africanos que operavam o comércio de escravos. A dominação europeia se restringia a um forte no litoral, de onde os europeus só podiam sair com autorização dos funcionários estatais", além disso, os reinos africanos passaram a depender do comércio de escravos para se manterem, trocando gente por armas conseguiam os recursos necessários para garantia de sua soberania. De acordo com Fausto (2009, p.24), "os negros escravizados no Brasil provinham de muitas tribos ou reinos, com suas culturas próprias - por exemplo, os iorubas, jejes tapas, haussás entre os sudaneses e os angolas, bengalas, monjolos, moçambiques entre os bantos".

Em termos de quantidade, a estimativa de Fausto (2009, p.24) é que entre "1550 e 1855 entraram pelos portos brasileiros 4 milhões de escravos, na sua grande maioria 
jovens do sexo masculino". Macedo (2013, p.105) confirma esta estimativa citando o "pesquisador brasileiro Luiz Felipe de Alencastro, que avalia em 10 milhões o número total de africanos transferidos para o Novo Mundo", destes, "aproximadamente 4 milhões de pessoas, portanto $40 \%$ do total, desembarcaram em portos brasileiros". Macedo (2013, p.99) afirma que se tratou "da maior emigração de toda a história da humanidade", uma verdadeira "Diáspora Africana".

Além das explicações econômicas e justificativas históricas em relação à escravidão do negro africano, a religião também era utilizada pela sociedade colonial em formação para especular sobre o problema pela ótica das teorias da maldição divina. Segundo Azzi (2008, p.28), existiam três teorias neste sentido: "a primeira delas afirmava que a escravidão era consequência do pecado de Adão e da maldição imposta ao homem de trabalhar com o suor de seu rosto. $O$ trabalho escravo evidenciava na sociedade humana a força dessa maldição"; numa outra versão, os africanos eram considerados descendentes de Caim, assim, "traziam ainda na carne a maldição divina ao primeiro homicida da humanidade", ou seja, ao matar seu irmão, Deus amaldiçoou Caim com um sinal para que não fosse morto e continuasse vivo expiando seu crime, a negritude da pele era este signo e, portanto, os negros deveriam pagar por esse pecado através do castigo da escravidão; a terceira teoria religiosa, citada por Azzi (2008, p.29) dava conta de que "os africanos eram os descendentes de Cam, o filho de Noé, amaldiçoado pelo pai por ter zombado de sua nudez, quando jazia embriagado após provar o fruto da videira", como o restante do mundo fora destruído pelo dilúvio, segundo a tradição judaica, "a maldição de Noé parecia ser ainda a mais atuante: daí serem os negros da África considerados com frequência como descendentes de Cam" que, por isso, também deviam pagar sua conduta reprovável com a maldição da escravidão. Estas narrativas bíblicas utilizadas de forma indevida na sociedade colonial em formação "isentava os portugueses de qualquer culpa, pois a escravidão fazia parte da predestinação dos africanos". Indo mais além, na interpretação destas doutrinas, "os escravocratas lusos passaram a se considerar como justiceiros divinos, o braço escolhido por Deus para aplicar à raça negra o castigo divino". Estas interpretações eram propagadas a nível popular, não há como determinar suas origens, mas a Igreja pouco fez para evitar sua disseminação. 
Porém, segundo Azzi (2008, p.28), a principal justificativa para a escravidão negra "era a doutrina da guerra justa. Os negros poderiam ser escravizados, desde que capturados num combate envolvendo interesses de promoção da fé no continente africano". Mas, na colônia não tinha como se saber como teria ocorrido seu aprisionamento. Macedo (2013, p.116) confirma que "uma das justificativas ideológicas ao aprisionamento das populações africanas era a sua posterior conversão ao cristianismo, antes da travessia do Atlântico muitos cativos eram batizados e começavam a receber os rudimentos da doutrina cristã". Neste ponto a Igreja participava ativamente do processo de instituição da escravidão ao se beneficiar pela iniciação do negro africano na religião ainda na África, com a finalidade de aumentar seu rebanho. Wright (2009, p.73) "mostra o ramo português dos jesuítas, amplamente coincidente com a esfera de ação da investida imperial lusitana, estendendo-se pela África".

\section{A UNIÃO ENTRE ESTADO E IGREJA CATÓLICA NO PROJETO COLONIAL BRASILEIRO}

Como colocado acima, a união do Estado português com a Igreja Católica no projeto colonial, já se iniciava no continente africano com a presença dos religiosos lá, continuando dentro dos navios negreiros onde a busca de novas almas pela conversão dos negros escravos encaminhados ao Brasil era de tal forma distorcida da realidade e imprópria para o momento que Hornaert et al. (2008, p.299), ao narrar o sacrifício e a morte mística de Cristo durante as cerimônias celebradas nos navios pelos missionários, afirma que os mesmos "eram capazes de celebrar a missa nos navios negreiros, onde o Cristo vivo estava sendo acorrentado, açoitado, amaldiçoado, sem mesmo perceberem o que estavam fazendo nem onde se realizava o verdadeiro sacrifício".

Assim, segundo Matos (2011, p.47), "o projeto colonial é apresentado como uma obra divina que visa à conversão dos gentios pela ação missionária da Igreja, apoiada pelo Estado", mas, na verdade, "o eixo ao redor do qual girava todo o processo de implantação da cristandade era a atividade comercial”, finalizando, este autor afirma 
ainda que a religião "era utilizada para dar ao projeto colonial uma legitimação de caráter sacral". Complementando, Hornaert et al. (2008, p.365) afirma que, dentro desta ideologia utilizada para justificar o projeto colonial, o cativeiro não teria "nada que ver com o sistema colonial pois the é anterior: os colonizadores nada mais fazem senão comprar (ou remir) os que já são escravos anteriormente".

Já dentro deste contexto de união, Fausto (2009, p.29) afirma que "as duas instituições básicas que, por sua natureza, estavam destinadas a organizar a colonização do Brasil foram o Estado e a Igreja Católica. Uma estava ligada à outra, sendo o catolicismo reconhecido como a religião do Estado". Mas, a Igreja estava subordinada ao Estado pelo mecanismo chamado de "padroado real" que consistia em "uma ampla concessão da Igreja de Roma ao Estado português, em troca da garantia de que a Coroa promoveria e asseguraria os direitos e a organização da Igreja em todas as terras descobertas". O principal direito da Igreja era o da exclusividade de ação nas novas terras conquistadas pelos portugueses, por outro lado o rei poderia recolher o dízimo dos fiéis, tributo correspondente a um décimo dos ganhos obtidos pelos mesmos em suas atividades. Nesta troca de favores, a Coroa teria obrigação de remunerar o clero e construir e zelar pela conservação dos edifícios da Igreja, mas, por outro lado, seria responsável por "criar dioceses e nomear bispos". A Igreja se constituía num "instrumento muito eficaz para veicular a ideia geral de obediência e mais restritamente de obediência ao poder do Estado", ou seja, "controle das almas". Resumindo a situação, segundo Hornaert et al. (2008, p.156) "os monarcas se constituíram como verdadeiros chefes espirituais das novas terras, por delegação do papa". Em sua análise, Hornaert et al (2008, p.161) afirma que essa "proteção do Estado trouxe sempre privilégios para a Igreja, mas significou sempre compromisso, e não muitas vezes opressão da Igreja" e, continuando "não resta dúvida de que o padroado foi uma instituição que atendeu melhor às exigências do regalismo do que as verdadeiras necessidades da Igreja do Brasil em formação". (HORNAERT et al., 2008, p.168)

Matos (2011, p.101) define o sistema do padroado como o estabelecimento de "um solene compromisso entre o Estado, na pessoa do rei e a Santa Sé, tendo em vista a 
propagação da fé cristã e a consolidação da Igreja", bem como a sua expansão e crescimento, mas segundo Hornaert et al. (2008, p.286) "o clero estava preso por causa deste problema do sustento financeiro" e, por isso mesmo, de acordo com Matos (2011, p.111), "a instituição do padroado não foi benéfica para a Igreja e sua missão evangelizadora. Cerceou a liberdade dela e a de seus representantes, impedindo o livre desempenho de sua tarefa primordial: o anúncio da boa nova de Jesus, visualizada em estruturas e modelos de justiça e fraternidade".

Esta união entre Estado e Igreja servia, principalmente, para justificar a ideologia do sistema colonial em relação à escravidão negra especificamente, conforme a análise de Hornaert et al. (2008, p.257), "a religião funcionava na maioria dos casos como uma lavagem cerebral no sentido de inculcar nos escravos as virtudes da obediência servil, da paciência passiva, da dependência, da entrega de sua dignidade". Continuando, Hornaert et al. (2008 p.367) afirma que os negros escravos adquiriram com o tempo, as virtudes do cativeiro, dentre elas, "a resignação" e, também "a mansidão, a paciência, a humildade, a submissão, finalmente a completa entrega da personalidade". De acordo com Azzi (2008, p.28) "na perspectiva dos lusitanos, a crença católica deveria ser também um instrumento importante para a manutenção da ordem social", da qual fazia parte o "estatuto escravocrata" em prol da própria metrópole. "Desse modo, um questionamento sério de sua legitimidade seria um atentado contra a estabilidade do próprio trono português. A instituição católica justificava o regime escravocrata". Hornaert et al. (2008, p.328) conclui a situação afirmando que "tudo se resume nisto: os africanos cristãos têm que entender a escravidão como um meio de salvação. Quem procura fugir dos engenhos para os quilombos vive em estado de pecado mortal. A obediência ao feitor e ao senhor de engenho é obediência a Deus". Portanto, de acordo, ainda, com Hornaert et al. (2008, p.340) aqueles religiosos que "doutrinaram os africanos thes ensinaram que os foragidos vivem em estado de pecado mortal, vão para o inferno, são condenados para sempre".

Hornaert et al. (2008, p.263) relata também, que o jesuíta Antônio Vieira afirmava que os escravos estavam em constante estado de rebelião tentando sempre fugir dos 
engenhos, mas aqueles que, conseguissem este intento, cairiam "em pecado mortal de desobediência e estavam pois excomungados." Por outro lado, ainda segundo Hornaert et al. (2008, p.337), "um escravo consciente de sua posição dentro da engrenagem social do colonialismo se converteria irremediavelmente num revoltado". Mas isto era exceção, pois a Igreja acabou colaborando na interiorização da ideologia do sistema colonial "na alma e no coração do povo pobre" utilizando o "ensino da moral".

Porém, diante de tudo que foi dito anteriormente, o problema central da escravidão negra no Brasil, diz respeito à falta de mão-de-obra existente para tocar o projeto colonial, Hornaert et al. (2008, p.258) chega a afirmar que escravidão era algo "estrutural. Sem escravidão não podia haver Brasil”. Azzi (2008, p.25) afirma também que "a numerosa presença africana no Brasil a partir de meados do século XVI foi o resultado da necessidade do braço escravo para o trabalho agrícola". Neste sentido, Fausto (2009, p.33) argumenta que "a escravidão foi uma instituição nacional. Penetrou toda a sociedade, condicionando seu modo de agir e de pensar. O desejo de ser dono de escravos, o esforço para obtê-los ia da classe dominante ao modesto artesão das cidades". Hornaert et al. (2008, p.259) complementa, afirmando que "não se encontra gente de trabalho para se contratar: o único remédio é ter escravos". Narloch (2011, p.83) destaca que no Quilombo de Palmares, até "Zumbi tinha escravos" e que os quilombolas atacavam povoados e engenhos próximos para obtêlos; "os escravos que por sua indústria e valor, conseguiam chegar aos Palmares, eram considerados livres, mas os escravos raptados ou trazidos à força das vilas vizinhas continuavam escravos". Era esta a mentalidade vigente e, segundo este autor, "na sua época, não havia nada de errado nisso". Moraes (1998, p.188) conclui, ressaltando que o problema da mão-de-obra na economia açucareira havia sido resolvido, mas, "a presença dos escravos negros no Brasil não se restringiu ao universo econômico, na realidade o ingresso incessante de negros como escravos até o século XIX marcou o cotidiano e o modo de vida no Brasil colonial e de forma permanente e definitiva a história do país". 
Em relação ao tráfico negreiro, o mesmo era considerado "também estrutural, inevitável e ao mesmo tempo insuportável para os que pensavam de maneira mais profunda" e suscitava "a mesma perplexidade", segundo Hornaert et al. (2008, p.321), esta reflexão fazia com que alguns teólogos aconselhassem "fechar os olhos" ou "não ter escrúpulos", pois, "na América, todo escrúpulo é fora de propósito"; mas outros, denunciavam com vigor o problema e suas consequências nefastas. Assim, somente seria possível "estudar a doutrina da Igreja no Brasil dentro deste movimento dialético que agitou os maiores espíritos que trabalharam na obra do evangelho aqui e sofreram profundamente em sentir que estavam engajados, querendo ou não, nos percursos coloniais".

\section{A IGREJA CATÓLICA COMO PROPRIETÁRIA DE TERRAS E ESCRAVOS}

Se a escravidão era uma "instituição nacional" e "estrutural" na sociedade brasileira, até a Igreja tinha necessidade da mão-de-obra negra para sua manutenção, utilizando-a em suas fazendas e colégios, pois, segundo Lima (2001, p.41), "dificilmente as obras jesuíticas poderiam subsistir, já que era vão esperar apoio governamental, apesar dos compromissos do padroado. Muitas, senão todas as instituições eclesiásticas, por motivos análogos ao indicado, seguiram pelo mesmo caminho e aceitavam a escravidão". Segundo Hornaert et al. (2008, p.220), a Coroa Portuguesa, pelo compromisso do padroado, colaborava com os missionários através da doação de terras, fazendo com que se tornassem "progressivamente senhores de grandes latifúndios e inúmeras fazendas, principalmente no norte do país". Assim, "quase todos os colégios dos jesuítas sustentavam-se mediante a administração de fazendas e engenhos recebidos como dotações ou heranças" de pessoas particulares que também doavam aos religiosos. Assunção (2003, p.30) reforça este ponto, afirmando que "no Brasil, os favorecimentos reais foram muitos e transformaram os religiosos em senhores de engenho e criadores de gado", dentre outras atividades; afirma ainda que os jesuítas não eram a única ordem sacerdotal a manter escravos. De acordo com Hornaert et al. (2008, p.220), "apenas os franciscanos e capuchinhos, não podendo aceitar doação de terra pelo voto de pobreza, viviam do patrimônio dos 
seus conventos e de esmolas". Em relação aos franciscanos, segundo Bueno (1997, p.39), eles "sempre se mantiveram ao lado do poder colonial, não se envolveram em polêmicas como os jesuítas". Por isso, "acabaram por constituir a ordem religiosa mais afinada com os desígnios do colonialismo", por suas atividades de benzer as propriedades, perdoar, justificar e promover a "escravidão e o ataque aos índios hostis", além de fornecer capelães para acompanhamento dos "bandeirantes ao sertão", dentre outras. Em relação aos beneditinos, Bueno (1997, p.39) relata que eram proprietários de inúmeros "prédios urbanos", "imensas fazendas" e muitos escravos, ressaltando que, "não eram os únicos: a prática fora inaugurada pelos próprios jesuítas já em 1549".

Assim, segundo Assunção (2003, p.32), muitos religiosos acabaram assumindo "o papel de senhores de engenho, a fim de conseguir uma boa produção, não só aceitaram a escravidão como usaram de violência contra os escravos". Alguns "bons" religiosos - como o Padre Jorge Benci, por exemplo -, chegavam até a defender um tratamento "mais humano" para os cativos, porém, estes mesmos religiosos não questionavam o sistema escravista em si, tido como algo estrutural como já descrito anteriormente. Mas, mesmo com esta preocupação em relação à forma de se castigar o escravo, não se excluía a aplicação das penas, conforme o erro cometido, "açoites moderados e prisões, por exemplo, eram práticas consideradas aceitáveis, e apenas punições de extrema violência, como lançar escravos vivos nas fornalhas, eram condenadas". Concordando com este ponto de vista, Hornaert et al. (2008, p.262) destaca que "os jesuítas tiveram até necessidade - segundo os imperativos inerentes à escravidão - de prender escravos em ferros", e continuando, o mesmo autor complementa afirmando que "o Padre Geral Francisco de Borja tinha proibido este abuso, mas a consulta provincial, reunida na Bahia em 1579, e presidida pelo próprio Anchieta cujo espírito humanista é universalmente conhecido, pediu que se retirasse esta proibição".

Assim, segundo Hornaert et al. (2008, p.41), "eram poucos os defensores da liberdade dos africanos e muitos os que apoiavam a escravidão", dentre eles "os jesuítas, intransigentes propugnadores do índio livre, porém, condescendentes com a 
escravidão negra institucionalizada, utilizando-a nos serviços de suas fazendas". Seria mais lógico, segundo Hornaert et al. (2008, p.258), "defender os africanos tanto quanto se defendiam os indígenas".

\section{A AÇÃO INDEPENDENTE DE ALGUNS RELIGIOSOS EM PROL DOS ESCRAVOS}

Portanto, diante deste quadro, uma grande característica da cristandade colonial é destacada por Hornaert et al. (2008, p.248), o de "uma cristandade em conflito" que era a verdadeira "expressão do sistema colonial, esta cristandade admitia a escravidão, consequência estrutural do colonialismo mercantilista, e consagrava deste modo uma não-fraternidade em flagrante oposição com a mensagem evangélica". E, continuando, "as virtudes teologais como a fé, a esperança, a caridade, foram interpretadas segundo o ponto de vista de uma sociedade que não podia sobreviver sem escravos".

Assim, segundo Assunção (2003, p.32), alguns "poucos jesuítas lutaram para mostrar as injustiças praticadas contra o negro e o horror da escravidão colonial". Já Hornaert et al. (2008, p.249) afirma que foram "numerosos casos de expulsão de membros da Igreja que ousavam levantar a voz contra a sistemática exploração dos pobres indígenas e africanos" e, complementando, Hornaert et al. (2008, p.291) destaca ainda que "apesar de todos estes condicionamentos em contrário houve sempre, no clero que atuava no Brasil, vozes discordantes, que procuravam colocar a vida sacerdotal em termos de missão evangélica e não em termos de expansão de um sistema religioso". Por fim, Hornaert et al. (2008, p.180) afirma que os diversos bispos "que protestaram ou simplesmente não se conformaram com as imposições da metrópole, ou tiveram dissensões com os governantes no Brasil" eram "chamados a Portugal para prestar contas de sua atuação ou simplesmente afastados da sede episcopal e exilados".

Já os jesuítas tentando amenizar o martírio dos negros escravos que aportavam no Brasil, de acordo com Hornaert et al. (2008, p.122), tiveram a sensatez de trazer padres nascido em Angola e, portanto, que conheciam a língua angolana, para o 
trabalho de catequese com os negros que chegavam aos portos brasileiros, um exemplo é o caso do Padre Pedro Dias (1622-1700) que muito se sensibilizou com a situação dos escravos africanos nos engenhos, aprendendo inclusive noções de medicina com a finalidade de prestar socorro aos mesmos.

Nesta questão da participação da Igreja no processo da escravidão negra no Brasil e, trabalhando em prol dos mesmos, vale destacar também, de acordo com Matos (2011, p.227), o papel das confrarias, constituindo-se numa "das poucas formas de associação permitidas à população de cor" em defesa de seus membros, "era uma organização aceita, protegida pela ação pessoal de reis e eclesiásticos que proporcionava ao homem de cor um instrumento para enfrentar situações de injustiça e sofrimento", através da solidariedade mútua. Na verdade, "não transformava e nem mesmo tentava pôr fim à escravidão", por isso, sob um outro ponto de vista de Matos (2011, p.229), acabaram por contribuir "para a preservação das relações de dominação e de submissão" dos seus participantes, pois, não permitiu a formação de "uma consciência de classe e, por conseguinte, onde inexistiu uma consciência política". Segundo Macedo (2013, p.118), principalmente a partir do "início do século XVII, multiplicaram-se na América, as irmandades negras, ou confrarias, como espaço de sociabilidade e de construção de identidade dos cativos", eram as "Irmandades de Nossa Senhora do Rosário ou de São Benedito". Suas lideranças "desempenhavam um papel não apenas religioso, mas também de intermediação política dos cativos com os senhores e com as autoridades". Foram nestas instituições que acabaram por ocorrer o "processo de ressignificação dos cultos e práticas das religiões tradicionais africanas, entre si, e com o catolicismo oficial", na formação do sincretismo da religiosidade brasileira.

Finalizando, segundo Hornaert et al. (2008, p.263) "a escravidão tem em si todas as barbaridades possíveis. Ela só pode ser administrada com brandura relativa quando os escravos obedecem cegamente e sujeitam-se a tudo". "O limite da crueldade do senhor está, pois, na passividade do escravo". Complementando, Hornaert et al. (2008, p.257) descreve, ainda, que "a paz nos engenhos era fruto da entrega da personalidade do escravo nas mãos do senhor", conforme dizia o abolicionista 
Joaquim Nabuco. "Este estado de guerra permanente era exercido de três modos, basicamente pelos castigos, pela espionagem, pela religião". E, "os missionários, sobretudo jesuítas, nem sempre se conformaram com este postulado da vida no Brasil, mas eles tiveram que ceder diante da lição do realismo". (HORNAERT et al., 2008, p.259)

Concluindo, diante de tudo que foi exposto acima, segundo Lima (2001, p.43), "não é difícil deduzir que as consequências morais, sociais e espirituais, advindas da escravidão foram as mais nefastas e os benefícios que nos trouxeram proporcionalmente reduzidos". Nesse mesmo sentido, Azzi (2008, p.18) afirma que "quanto aos resultados positivos com relação à conversão católica, pode-se dizer que foram bastante limitados, se confrontados com o ideal da formação cristã auspiciada pelos missionários". Entretanto, Azzi (2008, p.19) destaca ainda que "não se deve olvidar, enfim, a dedicação de muitos missionários à causa da fé, o sacrifício por eles dispendidos na tarefa da evangelização, redundando por vezes na sua própria morte".

\section{CONSIDERAÇÕES FINAIS}

A História do Brasil, desde seus primórdios, evoluiu a partir da união entre o Estado português e a Igreja Católica, que assumiu importantes funções a partir da implantação do sistema de colonização do país. Esta união foi fundamental para que a Coroa portuguesa conseguisse atingir seus objetivos coloniais, mas por outro lado, deveria colocar a Igreja Católica como única e exclusiva instituição religiosa a atuar dentro do território nacional visando atingir seu principal objetivo naquela época que era o aumento do seu número de seguidores.

Basicamente, são três as formas de se analisar a influência e a participação da Igreja Católica no episódio da escravidão negra no Brasil: a primeira delas é simplesmente desviando a atenção dos fatos ocorridos para o engrandecimento de alguns nomes dos seus quadros da época, enaltecendo seus feitos desvinculados da realidade e, consequentemente, valorizando a própria instituição; a segunda forma seria visualizando as ações da Igreja e dos religiosos de um modo crítico, porém, tentando situar este discurso dentro da mentalidade da época, ou seja, contextualizando a 
atuação da Igreja conforme os valores culturais, sociais, políticos e econômicos do tempo em que ocorreram, colocando a Igreja numa posição passiva diante dos desígnios da colonização e; por fim, a terceira forma, descrevendo os atos cometidos, mostrando a realidade de modo transparente e colocando a Igreja como sujeito ativo no processo, fazendo suas escolhas e opções de acordo com seus propósitos.

A escravidão tinha um caráter estrutural dentro da sociedade brasileira. Não sendo a escravidão do nativo indígena possível pela própria defesa promovida pelos religiosos, outra forma de mão-de-obra teria que ser encontrada para que funcionasse o projeto colonial. A escravidão do negro africano mostrou-se, desde o início, mais vantajosa por criar um novo negócio gerador de riquezas - o tráfico - e por resolver o problema da força de trabalho em si. Sem o trabalho do negro não seria viável a colonização do Brasil. Mas, para explicar e justificar esta barbárie em plena modernidade, um conjunto de ideias foi elaborado, baseado na religião e reforçado pela atuação da Igreja em conjunto com os interesses do Estado português. O fato é que seria difícil para a Igreja assumir uma posição contrária à escravidão negra também, pois a mesma não teria como apresentar uma nova alternativa viável para a colonização em termos de mão-de-obra.

O padroado real permitia o controle da Igreja no Brasil pelo Estado português, além de possibilitar a legitimação do sistema e de submeter os religiosos aqui instalados aos interesses mercantilistas da Coroa portuguesa. Esta união entre Estado e Igreja Católica tinha suas vantagens também para a Igreja, mas as amarras a ela impostas não permitiram o desenvolvimento de uma ação evangelizadora livre, em prol dos seus novos seguidores.

O fato é que a vida dos religiosos católicos que trabalharam no país no tempo do Brasil colônia, a partir da primeira viagem documentada dos portugueses, assim chamada a viagem do "Descobrimento", não foi fácil, pois foram obrigados a seguir as orientações e as diretrizes da Coroa Portuguesa, já que Roma era submissa e se calava frente às ordens de Portugal em assuntos relacionados ao Brasil. O interesse português estava relacionado primeiramente aos objetivos mercantilistas de cunho estritamente econômico e a manutenção dos religiosos no país dependia dos repasses financeiros 
do Estado português que eram sempre insuficientes. Qualquer questionamento por parte daqueles membros da Igreja que viviam no Brasil, em relação aos mandos e desmandos da Coroa portuguesa, era fortemente reprimido pela mesma. Além disso, eles enfrentavam as doenças tropicais, o ataque de índios, a incompreensão e violência dos colonos e dos representantes do governo português no país. Por outro lado, a Igreja Católica como instituição, em tempos de Reforma Religiosa que ocorria na Europa, negociou com o governo português a exclusividade da catequização e da conversão de novos adeptos e fiéis, ao custo de sua submissão aos interesses puramente econômicos da Coroa portuguesa. Para satisfação destes interesses, dois pontos principais contrários à filosofia de uma Igreja seguidora dos ensinamentos de Jesus Cristo se evidenciaram: 1) a exploração e o extermínio dos nativos indígenas e, 2) a exploração e escravidão dos negros africanos. As marcas da colonização foram, assim, com a influência e a participação da Igreja Católica: a exploração do ser humano pelo ser humano, a não-fraternidade, a injustiça, a violência, o terror e a morte.

Os preceitos e os dogmas da Igreja foram utilizados para justificar o sistema e para oprimir os mais fracos, ou seja, os nativos indígenas e os negros escravos africanos; muitos religiosos que para cá vieram, até tinham intenções "nobres", mas, atuaram, de um modo geral, ao lado dos interesses dos colonizadores, pois dependiam financeiramente dos cofres da Coroa portuguesa e eram reprimidos pela mesma quando discordavam de suas ordens. Até para terem uma independência relativa, as ordens religiosas tinham que reproduzir o sistema em suas propriedades, utilizandose da força de trabalho escrava para geração de recursos visando sua manutenção, e, assim também o fizeram sem quaisquer escrúpulos.

Enfim, este foi o quadro em que se deu a influência e a participação da Igreja Católica na implantação da escravidão negra africana no projeto colonial português para o Brasil a partir do século XVI.

\section{REFERÊNCIAS}

ASSUNÇÃO, Paulo. Os jesuítas no Brasil Colonial. São Paulo: Atual, 2003. 
AZZI, Riolando. A Igreja Católica na formação da sociedade brasileira. Aparecida, SP: Santuário, 2008.

BUENO, Eduardo. História do Brasil: Os 500 anos do país em uma obra completa, ilustrada e atualizada. 2. ed. São Paulo: Publifolha: Zero Hora/RBS Jornal, 1997.

FAUSTO, Boris. História concisa do Brasil. 2. ed. Reimpressão. São Paulo: Edusp, 2009.

HONAERT Eduardo et al. História da Igreja no Brasil: ensaio de interpretação a partir do povo: primeira época, Período Colonial. 5. ed. Petrópolis: Vozes, 2008.

LIMA, Maurílio Cesar de. Breve História da Igreja no Brasil. Rio de Janeiro: Restauro - Edições Loyola, 2001.

MACEDO, José Rivair. História da África. São Paulo: Contexto, 2013.

MATOS, Henrique Cristiano José. Nossa história - 500 anos de presença da Igreja Católica no Brasil. 3. ed. São Paulo: Paulinas, 2011.

MORAES, José Geraldo Vinci de. Caminhos das civilizações - História integrada: Geral e Brasil. São Paulo: Atual, 1998.

NARLOCH, Luiz. Guia politicamente incorreto da história do Brasil. 2. ed. São Paulo: Leya, 2011.

WRIGHT, Jonathan. Os jesuítas: missões, mitos e histórias; tradução André Rocha. Rio de Janeiro: Sinergia: Relume Dumará, 2009. 